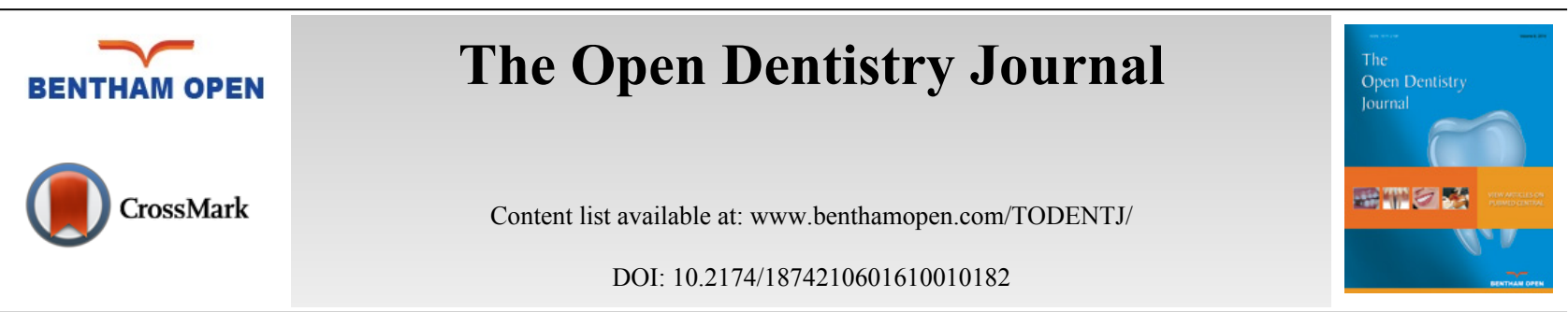

\title{
Dentin Cleaning Ability of an Amazon Bioactive: Evaluation by Scanning Electron Microscopy
}

Maria Fulgência C.L. Bandeira, ${ }^{1, *}$, Geisy R. Lima ${ }^{1}$, Patrícia P. Lopes ${ }^{1}$, Carina Toda ${ }^{1}$, Gisely N. Venâncio ${ }^{1}$, Greiciane A. Lima ${ }^{1}$, Marne C. de Vasconcellos ${ }^{1}$, Leandro M. Martins ${ }^{1}$, Fâbio C. Sampaio $^{2}$ and Nikeila C. de Oliveira Conde ${ }^{1}$

${ }^{I}$ School of Dentistry, Federal University of Amazonas, Manaus, AM, Brazil

${ }^{2}$ School of Dentistry, Federal University of Paraiba, João Pessoa-PB, Brazil

Received: December 30, 2015

Revised: January 10,2016

Accepted: January 28, 2016

Abstract:

The role of dentin cleaning is to remove debris that may impair adaptation and marginal sealing, quantitatively reducing microorganisms. The aim of this study was to investigate through scanning electron microscopy (SEM) the morphology of the dentin surface, cut and treated with copaiba oil emulsions (CO) and suspension of ethanol extract of propolis (EP). Twenty four upper premolars teeth, divided into eight groups ( $\mathrm{n}=3$ ), were used: G1: no cleaning, G2: air/water spray, G3: 10\% CO, G4: 10\% CO + A, G5: 30\% CO, G6: 30\% CO + A, G7: 1\% EP, G8: 2\% Chlorhexidine. The specimens were dentin discs (1 mm Ø). The SEM photomicrographs were classified and the results were: G1 - Debris dentin on the entire image / countless microorganisms, G2 and G7 - 50-100 debris / countless microorganisms and G3, G4, G5, G6 and G8 - 0-50 debris / countable microorganisms (50-100 colonies).

\section{Conclusion:}

The present results suggest that copaiba oil emulsions (CO) and suspension of ethanol extract of propolis (EP) have feasibility to be used as bioactive dental cleaning agents.

Keywords: Copaifera, dentin, integrative and complementary practices, phytotherapy, propolis, scanning electron microscopy.

\section{INTRODUCTION}

The cavity preparation is the biomechanical treatment of caries and other lesions of the tooth hard tissues forming the smear layer composed of organic and inorganic material, blood, saliva, oils from the rotary apparatus, microorganisms and their products [1 - 4].

Therefore, the dentin cleaning after cavity preparation is very important to remove, effectively, waste that can impair adaptation and marginal sealing and, at the same time, to reduce the amount of microorganisms and their products $[1,5]$.

A predominant trend in modern dentistry has been to search for biocompatible agents, especially those to be used in direct contact with tissues [6]. In this context, has been growing interest in evaluating plant extracts with a potential therapeutic application in dentistry [7].

The copaiba trees are native to the tropical regions of Latin America and West Africa [8]. Studies about the Gender Copaifera mostly are related to their chemical and pharmacological properties of their trunk secreted oil [9].

\footnotetext{
* Address correspondence to this author at the School of Dentistry, Federal University of Amazonas, Manaus, AM, Brazil; E-mail: fulgencia@ufam.edu.br
} 
The use of propolis was already described by the Assyrians, Greeks, Romans, Egyptians and the Incas, which has been further classified by Aristotle as a useful protective assent against infections and in the treatment of abscesses and wounds [10 - 12].

Considering that copaiba (Copaifera multijuga) and propolis are Amazonian biodiversity products that have antiinflammatory, antiseptic, antibacterial and antifungal properties, and that have shown promising results in studies as dental cleansers cavity [9, 12 - 15], the aim of this study was to investigate, through scanning electron microscopy (SEM), the morphology of the dentin surface, cut and treated with copaiba oil emulsions (CO) and suspension of ethanol extract of propolis (EP).

\section{MATERIALS AND METHODS}

The research was performed in Manaus, at the Federal University of Amazonas, in the Research Laboratory of the Faculty of Dentistry and in the Research Laboratory of the Department of Geosciences, Institute of Mathematical Sciences. The study protocol was approved by the local Research Ethics Committee (\#0276.0.115.000-11).

\section{Collection of Copaíba Oil-resin and of the Biotechnological Product (BP)}

The Copaifera multijuga (CM) oil-resin used was obtained from the Reservation Ducke, of the National Research Institute of Amazonia (INPA), with exsiccata a collection of dried specimens deposited in the herbarium of this institution. The biotechnological product (BP) was extracted from a natural resin.

\section{Formulations}

The Formulations with different concentrations were formulated at the School of Dentistry of the Federal University of Amazonas, in accordance with the demands of "Farmacopéia Brasileira" (2010) with the following compositions as demonstrated in Table $\mathbf{1}$.

Table 1. Components of the formulations used.

\begin{tabular}{|c|c|}
\hline Emulsions & Components \\
\hline $10 \% \mathrm{CO}$ & $10 \%$ copaíba oil-resin + Tween $80+$ tristerilized distilled water \\
\hline $\begin{array}{c}10 \% \mathrm{CO} \\
+\mathrm{BP}\end{array}$ & $10 \%$ copaíba oil-resin + Tween $80+1 \% \mathrm{BP}+$ tristerilized distilled water \\
\hline $30 \% \mathrm{CO}$ & $30 \%$ copaíba oil-resin + Tween $80+$ tristerilized distilled water \\
\hline $\begin{array}{c}30 \% \mathrm{CO} \\
+\mathrm{BP}\end{array}$ & $30 \%$ copaíba oil-resin + Tween $80+1 \% \mathrm{~PB}+$ tristerilized distilled water \\
\hline $1 \% \mathrm{PS}$ & $1 \%$ Propolis + Tween $80+$ tristerilized distilled water \\
\hline
\end{tabular}

\section{Ultrastructural Morphological Analysis of Dentin}

Twenty four extracted human maxillary pre-molars teeth (extracted for orthodontic reasons) were used in this study. The preparation of specimens followed the methodology proposed by Araújo et al. [2] with modifications in the production of smear layer [16]. The teeth were decontaminated with $0.2 \%$ solution of thymol (24 hours). The crown was separated from the root on the level of the cement enamel junction with a diamond disk. To make up the bodies of dentin it was used a cutter (PRESI Mecatome, Grenoble, France, p100) set with diamond double sided disc to the section in the mesio distal direction, the middle tooth. To make up the bodies of dentin used a cutter (PRESI Mecatome, Grenoble, France, p100) set with diamond double sided disc to the section in the middle tooth. It was used as a sandpaper (number 600) and water eroded about $1 \mathrm{~mm}$ dentin, thus producing the smear layer. The specimens were randomly divided into eight groups (Table 2), mounted on metal brackets from aluminum and treated with the test substances with the aid of microbrush (30 seconds).

Table 2. Group treatment by the substance utilized

\begin{tabular}{|c|c|}
\hline Groups $(\mathbf{n}=\mathbf{3})$ & Dentin Cleaning/treatment \\
\hline $\mathrm{G} 1$ & No cleaning \\
\hline $\mathrm{G} 2$ & Air/water spray (control) \\
\hline $\mathrm{G} 3$ & $10 \% \mathrm{CO}$ \\
\hline $\mathrm{G} 4$ & $10 \% \mathrm{CO}+\mathrm{BP}$ \\
\hline $\mathrm{G} 5$ & $30 \% \mathrm{CO}$ \\
\hline
\end{tabular}


(Table प) contd.....

\begin{tabular}{|c|c|}
\hline Groups (n=3) & Dentin Cleaning/treatment \\
\hline G6 6 & $30 \%$ CO + BP \\
\hline G7 & $1 \%$ OS \\
\hline G8 & $2 \%$ Chlorhexidine \\
\hline
\end{tabular}

The specimens were examined and photographed by SEM (QUANTA Model 250 - FEI) in the environmental friendly way. The cleaning ability of dentin was evaluated by scoring of debris introduced by Metzger et al. [17] system. Three independent observers analyzed each of the photomicrographs, which were coded and randomly mixed so that the images were reviewed in a blind way. Examiners were initially calibrated with the reference image SEM. When all three examiners independently agreed on a score, it was recorded. When disagreement occurred, all three discussed the sample and its scoring, and an agreed score was reached. The presence of debris was evaluated from images with magnification of $665 \mathrm{X}$ using a 5-point scale (Table 3) and the results were dichotomized into "clean" dentin (scores 1, 2 and 3) or "dirty" dentin (scores 4 and 5).

The collected data were analyzed as the mean of debris presence in each photomicrography and then organized and compared by descriptive statistical analysis.

Table 3. Evaluation of debris by its presence/absence.

\begin{tabular}{|l|}
\hline $1-$ Absence of debris / absence of microorganisms \\
\hline $2-$ Lack of debris / countable microorganisms (1-50 colonies) \\
\hline 3 - Presence of debris $(0-50$ debris $)$ / countable microorganisms (50-100 colonies) \\
\hline $4-$ Reduction of debris (50-100 debris) / countless microorganisms \\
\hline $5-$ Dentin debris on the entire image / countless microorganisms \\
\hline
\end{tabular}

\section{RESULTS}

Micrograph made from the control group (without dentin surface treatment) showed a countless amount of debris and microorganisms (score 5). In specimens with treatment air/water spray was reduced, however, the presence of debris was very wide in large amount (score 4).

In micrograph with the specimens treated with $1 \%$ PS had less debris (50-100) as compared to the group without dentin surface treatment and countless microorganisms, not getting an effective cleaning of the dentin surface. It was rated as "dirty" dentin because it had the score 4, similar to the treatment group air/water spray.

For other forms of cleaning, $2 \%$ Chlorhexidine, $10 \% \mathrm{CO}, 10 \% \mathrm{CO}+\mathrm{BP} 30 \% \mathrm{CO}$ and $30 \% \mathrm{CO}+\mathrm{BP}$, all were effective and equal in cleaning. The score was 3 in such groups, because debris was present there (0-50 debris) and microorganisms counts (50-100 colonies) where none of the samples was characterized with scores 1 and 2 (Fig. 1).

\section{DISCUSSION}

The dentin surfaces were prepared using tungsten carbide bur and spoon excavator producing smear plugs in the tubular orifices [1]. During cavity preparation, the surface of bond will be covered by a smear layer which is not firmly attached to the tooth surface, so, it is important to know the role of the smear layer in dentin bond strength [4].

Cleaning restorative cavity agents can be classified into two groups: demineralizing which are acids, and nondemineralizing, which are germicides and alkalizing [18]. An example can be taken where $2 \%$ Chlorhexidine and can be added in this group $1 \% \mathrm{EP}, 10 \% \mathrm{CO}, 10 \% \mathrm{CO}+\mathrm{BP}, 30 \% \mathrm{CO}, 30 \% \mathrm{CO}+\mathrm{BP}$ and $1 \% \mathrm{PS}$, since they removed the dentin smear layer, with no exposition of dentinal tubules.

After analysis of specimens through photomicrographs of the $2 \%$ Chlorhexidine, it was found that this substance removed the smear layer, being classified as score 3 (presence of debris 0-50 and 50-100 colonies of microorganisms). The same result was obtained in the study of Bengston et al. [19], that $2 \%$ Chlorhexidine was able to remove the superficial dentin smear layer after investigation through SEM. Emulsions based on $10 \% \mathrm{CO}, 10 \% \mathrm{CO}+\mathrm{BP}, 30 \% \mathrm{CO}$ and $30 \% \mathrm{CO}+\mathrm{BP}$ achieved the same score of $2 \%$ Chlorhexidine, which is considered as the gold standard for presenting substantivity, being bacteriostatic and bactericidal [20]. 

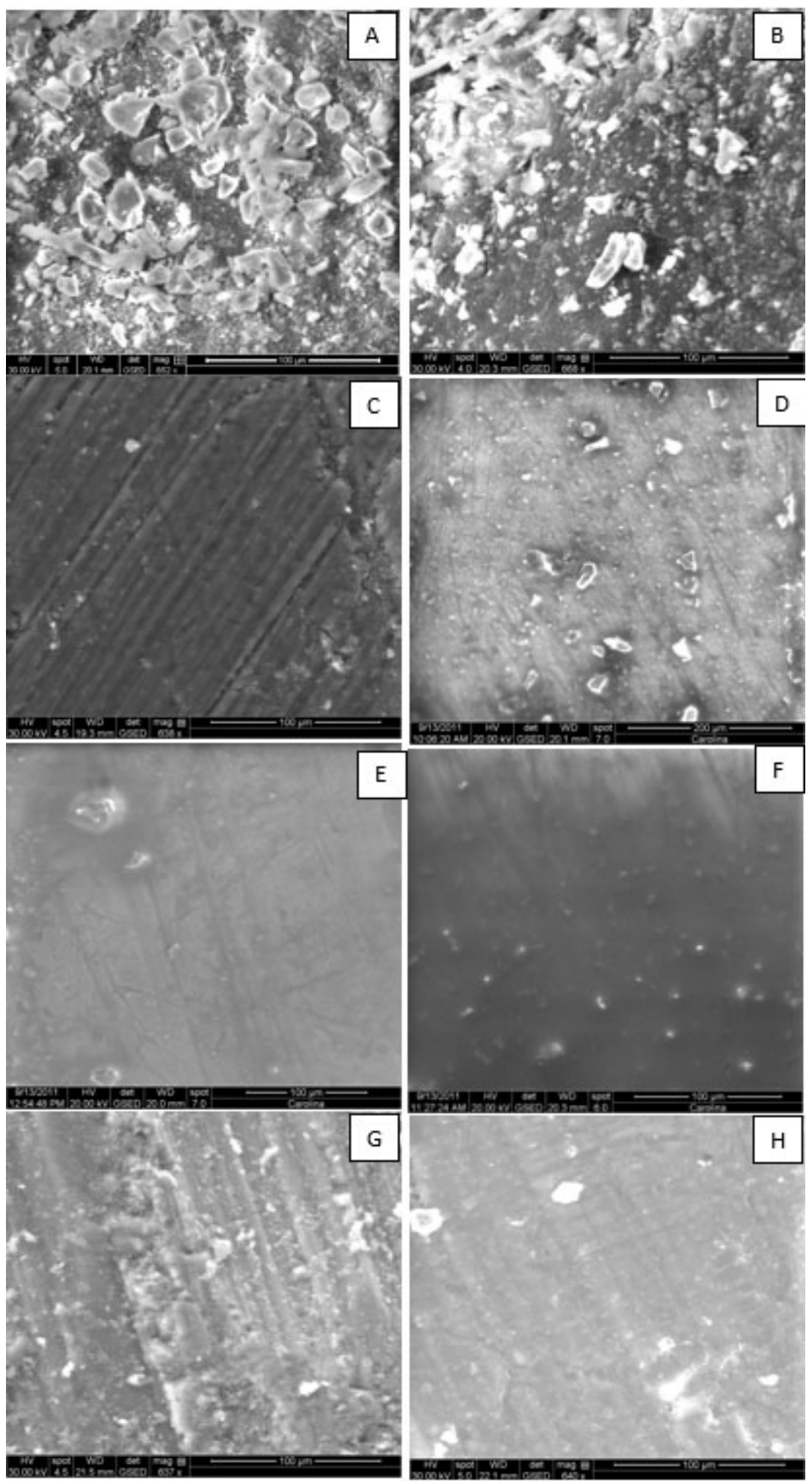

Fig. (1). Scanning electron microscopy micrographs representative of the eight groups: A) G1: no cleaning; B) G2: air/water spray; C) G3: 10\% CO; D) G4: 10\% CO + A; E) G5: 30\% CO; F) G6: 30\% CO + A; G) G7: 1\% EP; H) G8: 2\% Chlorhexidine.

Group 8 (1\% EP) micrograph showed a compliant layer with irregular smear layer corroborating preview studies of Geraldini; Salgado; Rode [10] that propolis solutions partially removed the smear layer. However, studies with propolis prove its antimicrobial, antioxidant, anti-inflammatory, immunomodulatory, hypotensive, healing, anesthetic, anticancer, anti-HIV and anticariogenic properties [13, 15, 21], allowing another way to use it in Dentistry, as in restorative dentistry, propolis can be used to decrease permeability of the dentin and to direct pulp capping in order to 
create restorative dentin [22].

Sales-Peres et al. [23] evaluated two kinds of propolis gel and under the conditions of the study, they showed capacity of partially obliterating the dentin tubules, concluding that it can be a good option in the treatment of patients with dentin sensitivity, although the application of $10 \%$ and $30 \%$ propolis gels did not seem to reduce the hydraulic conductance of dentin in vitro.

Emulsions of $10 \% \mathrm{CO}, 10 \% \mathrm{CO}+\mathrm{BP}, 30 \% \mathrm{CO}$ and $30 \% \mathrm{CO}+\mathrm{BP}$ promoted some kind of change in the surface layer morphology, however, the view was hampered by the addition of biotechnological products and high concentration of the emulsions, forming a thick layer on the surface. But it is noteworthy that below this layer it is a probability that bacterial activity may not occur since the copal has been scientifically proven to have antibacterial action, anti-inflammatory, antiseptichealing and antitumor properties [24, 14].

\section{CONCLUSION}

The dentin surface morphology shown in the SEM suggests that copaiba oil emulsions (CO) and suspension of ethanol extract of propolis (EP) have the feasibility to be also used as bioactive dental cleaning agents. Furthermore, in vitro and in vivo studies should be conducted to clarify the real action of the formulations on the dentin surface.

\section{CONFLICT OF INTEREST}

The authors confirm that this article content has no conflict of interest.

\section{ACKNOWLEDGEMENTS}

This study was financed by the National Council for Scientific and Technological Development - CNPq in Project MCT/CNPq/CT-Amazonia. Process No. 406457/2013-1.

\section{REFERENCES}

[1] Ajilal SK, Sam RJ, Babu R, Suganthan P. Morphological changes in the caries excavated dentin prepared by rotator, Carisolve TM and Er, Cr: YSGG Laser (BiolaseTM) instruments: A scanning electron microscopic evaluation. Int J Laser Dent 2012; 2(1): 1-6. [http://dx.doi.org/10.5005/jp-journals-10022-1009]

[2] Araújo MA, Rode SM, Vilella LC, Gonçalves RD. Avaliação qualitativa do efeito de agentes de limpeza na camada de lama dentinária: Estudo ultra-estrutural em microscopia eletrônica de varredura. Rev Odontol Univ Sao Paulo 1998; 12(2): 99-104. [http://dx.doi.org/10.1590/S0103-06631998000200003]

[3] Busato AL. Dentística: Restaurações estéticas. São Paulo: Artes Médicas 2002.

[4] Van Meerbeek B, De Munck J, Yoshida Y, et al. Buonocore memorial lecture. Adhesion to enamel and dentin: current status and future challenges. Oper Dent 2003; 28(3): 215-35. [PMID: 12760693]

[5] Rode SM, Santos JF. Limpeza cavitária - remoção da camada de "smear". Rev Bras Odontol 1990; 47(5): 46-51.

[6] Estrela C, Holland R. Calcium hydroxide: study based on scientific evidences. J Appl Oral Sci 2003; 11(4): $269-82$. [http://dx.doi.org/10.1590/S1678-77572003000400002] [PMID: 21394401]

[7] Costa EM, Evangelista AP, Medeiros AC, Dametto FR, Carvalho RA. In vitro evaluation of the root canal cleaning ability of plant extracts and their antimicrobial action. Braz Oral Res 2012; 26(3): 215-21.

[http://dx.doi.org/10.1590/S1806-83242012000300006] [PMID: 22641440]

[8] Veiga-Junior VF, Pinto A. O gênero Copaifera. Quim Nova 2002; 25(2): 273-86. [http://dx.doi.org/10.1590/S0100-40422002000200016]

[9] Valdevite LM. Estudo do efeito in vitro de extrato das folhas e do óleo-resina de copaíba sobre fatores de virulência de Streptococcus mutans, relacionado à cárie dental. In: Ribeirão Preto: Dissertação de Mestrado em Ciências Farmacêuticas, Universidade de São Paulo 2007 ; p. 129.

[10] Geraldini CA, Salgado EG, Rode SM. Ação de diferentes soluções de própolis na superfície dentinária - Avaliação ultra-estrutural. Rev Fac Odontol Univ Nac (Cordoba) 2000; 3(2): 37-42.

[11] Matsuno T. O efeito terapêutico da própolis. São Paulo: Nair Tazue Itice 1997.

[12] Pereira AS, Seixas FR, Aquino Neto FR. Própolis 100 anos de pesquisas e suas perspectivas futuras. Quim Nova 2002; $25(2)$ : 321-6. [http://dx.doi.org/10.1590/S0100-40422002000200021]

[13] Ishida VF, Negri G, Salatino A, Bandeira MF. A new type of Brazilian propolis: Prenylated benzophenones in propolis from Amazon and effects against cariogenic bacteria. Food Chem 2010; 125(3): 966-72.

[http://dx.doi.org/10.1016/j.foodchem.2010.09.089] 
[14] Vasconcelos KR, Veiga Junior VF, Rocha WC, Bandeira MF. In vitro assessment of antibacterial activity of a dental cement constituted of a Copaifera multijuga Hayne oil-resin. Rev Bras Farmacogn 2008; 18(Suppl. 0): 733-8. [http://dx.doi.org/10.1590/S0102-695X2008000500017]

[15] Park YK, Ikegaki M, Alencar SM. Determinação das atividades citotóxicas e anti- HIV dos extratos etanólicos de própolis coletadas em diferentes regiões do Brasil. Rev Mensagem Doce 2000; 58: 2-10.

[16] Shin TP, Yao X, Huenergardt R, Walker MP, Wang Y. Morphological and chemical characterization of bonding hydrophobic adhesive to dentin using ethanol wet bonding technique. Dent Mater 2009; 25(8): 1050-7. [http://dx.doi.org/10.1016/j.dental.2009.03.006] [PMID: 19371945]

[17] Metzger Z, Teperovich E, Cohen R, Zary R, Paqué F, Hülsmann M. The self-adjusting file (SAF). Part 3: removal of debris and smear layer-A scanning electron microscope study. J Endod 2010; 36(4): 697-702. [http://dx.doi.org/10.1016/j.joen.2009.12.037] [PMID: 20307746]

[18] Mondelli J. Proteção do Complexo Dentinopulpar. São Paulo: Artes Médicas - EAP-PCD 1998.

[19] Bengtson CR, Bengtson AL, Bengtson NG, Turbino ML. Efeito da Clorexidina 2\% na resistência de união de dois sistemas adesivos à dentina humana. Pesq Bras 2008; 8(1): 51-6.

[20] Zanatta FB, Rösing CK. Clorexidina: Mecanismo de ação e evidências atuais de sua eficácia no contexto do biofilme supragengival. Scientific-A. Odontoped Clin Int 2007; 8(1): 51-6.

[21] Koo H, Vacca Smith AM, Bowen WH, Rosalen PL, Cury JA, Park YK. Effects of Apis mellifera propolis on the activities of Streptococcal glucosyltransferases in solution and adsorbed onto saliva-coated hydroxyapatite. Caries Res 2000; 34(5): 418-26. [http://dx.doi.org/10.1159/000016617] [PMID: 11014909]

[22] Więckiewicz W, Miernik M, Więckiewicz M, Morawiec T. Does propolis help to maintain oral health? Evid Based Complement Alternat Med 2013; 2013: 351062. [http://dx.doi.org/10.1155/2013/351062] [PMID: 23365605]

[23] Sales-Peres SH, Carvalho FN, Marsicano JA, et al. Effect of propolis gel on the in vitro reduction of dentin permeability. J Appl Oral Sci 2011; 19(4): 318-23.

[http://dx.doi.org/10.1590/S1678-77572011005000004] [PMID: 21956588]

[24] Bandeira MF, Oliveira MR, Pizzolito AC, Benatti-Neto C, Jorge-Neto J. Estudo farmacológico preliminar de Copaifera multijuga (óleo de copaíba). J Bras Clin Estet Odontol 1999; 3(16): 39-41.

(C) Bandeira et al: Licensee Bentham Open.

This is an open access article licensed under the terms of the Creative Commons Attribution-Non-Commercial 4.0 International Public License (CC BY-NC 4.0) (https://creativecommons.org/licenses/by-nc/4.0/legalcode), which permits unrestricted, non-commercial use, distribution and reproduction in any medium, provided the work is properly cited. 